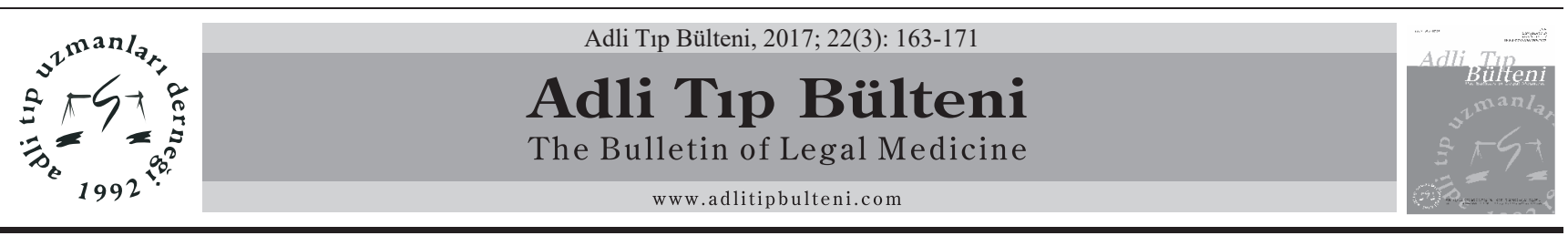

\title{
Tek Yumurta İkizlerinin EI Yazılarının Adli Belge İncelemesi Açısından Değerlendirilmesi
}

\author{
Evaluation of Handwritings of Identical Twins by Forensic Handwriting Principles
}

Behice Şeyda Türedi

Van Il Emniyet Müdürlüğü, Van

\begin{abstract}
Özet
Amaç: Adli bilimler alanında tek yumurta ikizleri ile ilgili dikkat çeken konulardan biri el yazılarıdır.

$\mathrm{Bu}$ araştırmada; tek yumurta ikizlerinin el yazılarının ne derece benzerliklerinin olduğunun tespit edilmesi, genetik benzerliklerin etkisinin adli belge inceleme açısından değerlendirilmesi amaçlanmıştır.

Gereç ve Yöntem: Çalışmamızda; "Atatürk'ün Gençliğe Hitabesi”" gönüllü yetişkin 100 ikize yazdırılmıştır. Yazılardaki “a, b, d, g, m, r, ş, u, v, y, z" harfler büyüteç ve cetvel yardımıyla incelenmiştir.

Bulgular: Analizleri yapılan değişken (ikizlerin cinsiyetleri, yaşları, aynı meslekte bulunmaları, eğitim seviyelerinin aynı olması, aynı evde yaşama süreleri, yazıyı kullanma sıklıkları, yazı yazarken çifti ile aynı eli kullanmış olmaları) ile el yazılarının benzerlik oranları üzerinde istatistiksel açıdan anlamlı farklılıkları bulunmamıştır ( $p>0.05)$. $50 \mathrm{ikiz}$ çiftin en fazla benzer olarak kullandığ 1 harf "d" harfi olup (\%56), en az benzer olarak kullandıkları harf "m" harfi (\%14) olarak tespit edilmiştir. Kadın ikiz çiftlerin el yazılarının, erkek ikiz çiftlere göre daha fazla benzerlik gösterdiği tespit edilmiştir. Kadın ikizlerin el yazılarındaki benzerlik oranları maksimum $\% 90.9$ minimum $\% 0$ iken; erkek ikizlerin el yazılarındaki benzerlik oranları maksimum: $\% 54.54$ minimum $\% 0$ 'dır.

Sonuç: Çalışmamızda el yazıları yüksek oranda benzerlik gösterse bile iki el yazısının tamamen benzer olamayacağı bilimsel gerçeğini destekleyen sonuçlar elde edilmiştir. Sonuçlar el yazılarının kimliklendirme çalışmalarında tanı koydurucu özellik taşıması açısından önemlidir.
\end{abstract}

Anahtar Kelimeler: Adli El Yazıs1; El Yazı İncelemesi; El Yazısı Karşılaştırma Kriterleri; Tek Yumurta İkizleri.

\begin{abstract}
Objective: In the field of forensic science, one of the most noteworthy topics about identical twins is hand writing.

In this study; It is aimed to determine the degree of similarity of the handwritings of the identical twins and to evaluate the effect of the genetic similarities in terms of examination of the judicial documents.

Materials and Methods: In our study; “Atatürk'ün Gençliğe Hitabesi"- "Atatürk's Speech to Youth" is printed on 100 voluntary adults. Letters "a, b, d, g, m, r, ş, u, v, y, z" were examined with the aid of a magnifying glass and ruler.
\end{abstract}

Results: There were no statistically significant differences in the similarity rates of the handwritten characters with the variables analyzed (gender of twins, age, occupation of the same profession, same level of education, residence time in the same household, frequency of use of writing, $(\mathrm{p}>0.05)$. The letter " $\mathrm{d}$ " $(56 \%)$ used by 50 twin pairs was used as the most similar letter, and the letter " $\mathrm{m}$ " (14\%) was used as the least similar letter. It has been found that the handwritings of female couples show more similarity than male couples. The similarity rates of female twins in their handwriting were $90.9 \%$ maximum, minimum $0 \%$; The similarity ratios of the male twins to the handwriting maximum: $54.54 \%$, minimum $0 \%$.

Conclusion: Even though the handwriting is highly similar in our work, we have achieved results that support the scientific truth that the two handwriting cannot be quite similar. The results are important in terms of diagnostic features in the identification of handwritings.

Keywords: Forensic Handwriting; Handwriting Comparison Criteria; Handwriting Examination; Identical Twins.

\section{Giriş}

El yazısı beynimizin istemsizce denetlediği el, kol, parmak, eklem ve adalelerin kalemi yönlendirmesi ile oluşan düşüncelerimizin grafiksel bir ifadesidir. Yüzmek, bisiklete binmek, yemek yemek vb. gibi yazı yazmak da

Sorumlu Yazar: MSc. Behice Şeyda Türedi

Van İl Emniyet Müdürlüğ̈̈, Van

E-mail: behiceseyda@gmail.com

* Bu çalışma Toronto, Ontario, Kanada'da 21-25 Ağustos 2017 tarihleri arasında gerçekleştirilen "21 st Triennial Meeting of the International Association of the Forensic Sciences 2017 (IAFS) 'da poster bildiri olarak sunulmuştur.

Geliş:16.07.2017 Düzeltme:10.08.2017 Kabul:05.10.2017 şartlı bir reflekstir (1). Yedi notadan sonsuz beste yapmak, yine sınırlı sayıda renkle sayısını bilemediğimiz kadar tablo ve resim yapmak mümkündür. Adli belge incelemelerinde dikkat edilmesi gereken husus alfabeyi oluşturan harflerin sayısı sınırlı olmasına rağmen; aynı harflerin farklı yazarlar tarafindan farklı icra edilebilmesidir. Adli belge inceleme uzmanı yazının benzerlik/ benzemezlik özelliğini ortaya koymalıdır (2). Her yazı bir hareket izi taşır ve belli bir yazı olgunluğuna ulaşmış bulunan herkes yazısını diğerlerinden ayıran kişisel bir yazıya sahiptir (3). Amerikan Adli Belge İnceleme Uzmanları Derneği (American Board of Forensic Document Examiners, ABFDE) tarafindan yapılan bir araştırmaya 
göre günümüzde incelenen belgelerle ilgili hatalı rapor yazma oranı yüzde 4,3 gibi oldukça düşük orandadır (4). Farklı ülke ve bölgelerde yapılan araştırmalar mevcut hata paylarının daha da düşürülebilmesi için harcanan teknolojik ve eğitsel çabaların ifadesidir (5). Yazma eylemi küçük yaşta başlayan öğrenme ve uygulama dönemi sonrası zamanla şekillenen en son artık sabitleşti denildiğinde bile sürekli küçük değişimlere açık olan bir mekanizmadır. Bu nedenle iyi bir adli belge inceleme uzmanı el yazısının şekillenmesinde önem arz eden durumlardan olabildiğince haberdar olmalıdır. Ancak bu farkındalık sayesinde gördüğü değişiklikleri ve farklılıkları sağlıklı yorumlayıp değerlendirebilir (6). Adli belge inceleme uzmanı, belgelerle ilgili araştırılan gerçeklerin ortaya çıkması hususunda uzmanlaşmış ve gerekli donanıma sahip kişidir. Bir belge inceleme uzmanının sadece el yazısı, makine yazısı üzerinde uzmanlaşması yeterli olmayıp aynı zamanda tahrifatlı belgeler, mürekkep ve kâğıt analizi, sahtecilik ve bunların hazırlanmasında kullanılan tüm teknik tertibat hakkında bilgili olması gerekir ve elde ettiği bilgileri yorumlayabilmesi gerekmektedir (7). Günümüzde teknolojik gelişmelerin ve bilgiye ulaşabilme yolunda atılan adımların adli bilimlerde kullanılan tespit yöntemlerini teknolojik bakımdan zenginleştirmektedir. Fakat bunun yanı sıra suç amaçlı girişimlerin ve yazı geliştirme yöntemlerinin de teknolojik temelini sürekli geliştirdiği bilinmektedir Böylesi bir durum, adli bilimler açısından el yazısını tanımanın ve kişisel bilgiler eşliğinde yorumlayabilmenin suça karşı alınacak tedbirlerin geliştirilmesinde taşıdığı işlevi bir kez daha gözler önüne sermektedir.

Günümüzde kullandığımız alfabede Türkçede bulunan seslere göre düzenlenmiş 29 harf bulunmaktadır. Latin alfabesinde olduğu gibi Türk alfabesinde de her harf birer küçük ve büyük yazım şekli ile ifade edilir. Bu semboller büyük ve küçük harfler olarak adlandırılır. Küçük ve büyük harfler okunuş itibariyle tümüyle aynı olmakla birlikte yazılış olarak çoğunluğu farklı özellikler göstermektedir (8).

\section{Temel olarak bireysel el yazısı karakteristikleri;}

- Çizgi kalitesi - yazarın yazma yeteneğine bağlı bir özelliktir,

- Kelime ve harflerin birbiriyle olan mesafeleri,

- Harflerin genişlik, boyut ve birbirleri ile olan orantısal ilişsileri,

- Kalem kaldırma ve ayrılmaları,

- Temas çizgileri ve bağlantı noktaları,

- Başlama ve bitiş çizgileri,

- Alışılmamış harf formasyonları,

- Eğim,
- Yatay düzlemle ilişkisi,

- Harflerin yapılışındaki artistik hareketler veya süsleme biçimleri,

- Noktalama veya işaretleme alışkanlıkları ve biçimleri şeklinde sıralanabilir (9).

Tek yumurta ikizleri tıp literatüründe demonozigotik ikizler olarak da adlandırılmakta ve babadan gelen bir sperm ile anneden gelen bir yumurtanın birleşmesi sonucu döllenmiş tek yumurtadan oluşurlar. Zigotun belli bir süre sonra ikiye ayrılması neticesinde iki farklı embriyo gelişmeye başlar ve bu bölünme tek yumurta ikiz gebeliğe yol açar (10). Tek yumurta ikizlerinin bire bir aynı genetik, sosyolojik, psikolojik ya da biyolojik özellikleri göstermediği gerçeği çoğunlukla fiziksel koşulların değişkenliği ile yakından ilintilidir (11). Hem çevresel hem epigenetik araştırma bulguları doğrulamaktadır ki, tek yumurta ikizleri arasındaki benzerlik ve farklılıkları ayırt edebilmek için ikiz bireylere yönelik kişisel değerlendirmeler yapmak gerekmektedir (12).

İkiz çiftlerde, el yazısını oluşturan karakterlerin ve kelimelerin ilişkisi ile yazının şekli ve stili birbirine çok benzer niteliktedir. Fakat aynı zamanda her bir ikiz bireyin el yazısında ayırt edici özellikler yer almaktadır. Her ne kadar ikiz çiftlerin el yazıları arasında yüksek oranda bir benzerlik söz konusu olsa da, bu tür ayırt edici özellikler kişisel el yazısını belirleyen temel unsurlar olarak karşımıza çıkmaktadır (13). İkizlerin el yazısının ayırt edilebilmesi için y1llar süren araştırmalar sonucunda günümüzdeki bilgi seviyesine ulaşılmış, çeşitli teknikler geliştirilmiş ve el yazısı örnekleri üzerinde uygulanabilirlikleri geliştirilmiştir. Böylelikle özellikle adli bilimler açısından ikizlerin el yazısını ayırt etme kabiliyeti önemli ölçüde etkinleştirilmiştir. Her ne kadar çalışmalar neticesinde ikizlerin el yazısını ayırt etmenin daha karmaşık bir süreç olduğu gerçeği ile karşılaşılsa da adli yazı tanıma süreçlerinin farklı bileşenler üzerinden uygulanılarak ve teknolojik ekipmanlar kullanılarak ikiz el yazısı tanımlamasında başarılı sonuçlar alındığı bildirilmektedir (14). Çalışmamızda; farklı kişilerin yazdığı yazıların aynı olamayacağı bilimsel gerçeğinden hareketle, tek yumurta ikizlerinin el yazılarının birbirleri ile ne derece benzerlikler gösterdiğinin tespit edilmesi, genetik benzerliklerin el yazıları üzerinde herhangi bir ay1rıcı unsur olup olmadığının araştırılması, cinsiyetin yazılar üzerindeki etkisinin belirlenmesi amaçlanmıştır.

\section{Gereç ve Yöntem}

Çalışma Ankara Üniversitesi Etik Kurulu'nun 22.02.2016 tarih ve 85434274-050.04.04/13476 sayıl1 izni kapsamında gerçekleştirilmiştir. Çalışmanın evreni ülkemizdeki 18 yaş üzeri gönüllü tüm tek yumurta ikiz- 
leri olacak şeklinde belirlenmiş olup, ikizler toplumun tamamına orantılı bir şekilde dağılmadığından kota örnekleme yöntemi kullanılmıştır. Tek yumurta ikizlerine ulaşmak için Ankara ilinden başlanılmış ve çalışmaya katılan ikizlerden de yardımlar alınarak çevrelerindeki ikizlere ulaşılmıştır. Gönüllü olan 18 yaş ve üzeri, en az ortaokul mezunu, sağlıklı tek yumurta ikizleri gönüllü katılım formunu okuyarak imzalamışlardır. Çalışmanın amacına uygun bazı değişkenler sınıflandırılarak bir anket formu hazırlanmıştır. Hazırlanan bu form "cinsiyet, yaş, dominant olarak kullanılan el, öğrenim durumu, meslek, günlük hayatta yazıyı kullanma derecesi, ikizi ile olan birliktelik süreleri ve yazı yazmayı etkileyecek herhangi bir hastalık geçirip geçirmediği” bilgilerini içermektedir. Gönüllü tek yumurta ikizi katılımcılar küçük ve büyük harf içeren yaklaşı 180 kelime ve 1380 harften oluşan "Atatürk'ün Gençliğe Hitabesi” metnini çizgili/çizgisiz beyaz kâğıda mavi ya da siyah tükenmez kalem ile yazmışlardır. Alınmış olan el yazı örneklerinden incelemeye uygun olan 50 çift ikiz tarafindan yazılan toplamda 100 adet el yazısı örneği incelemeye alınmıştır. Araştırma Kriminalistik yüksek lisans tezi olarak araştırmacı ile beraber 14 yıllık adli tıp uzmanı, 3 yıllık adli belge inceleme sertifika sahibi olan öğretim üyesi eşliğinde gerçekleştirilmiştir. Çalışma, gerekli kaynakların toplanması, sağlıklı gönüllülerin örnek el yazılarının alınması, alınan el yazı örneklerinin incelenerek değerlendirmeler yapılması ile aşamalar halinde devam etmiş ve tamamlanmıştır.

El yazılarındaki harflerin tersimlerini, başlama ve bitiş güzergâhlarını, kalem kaldırma sayılarını, yapılış yönleri ve özelliklerini değerlendirmede maksimum $3 \mathrm{x}$ büyütme gücüne sahip, 6 diyoptri ve 1,97"/50 mm mercek çapında 6 LED ışıklı pil ile çalışan el büyüteci kullanılmıştır. Harflerin boyutlarının karşılaştırılması için ayrıca 30 mm'lik hatve cetveli kullanılmıştır. Metin içerisindeki seçilen harfler büyüteç ile incelenerek, ikiz eşinin el yazısı ile karşılaştırmalar yapılmıştır. Çalışmada tek yumurta ikizlerinin el yazılarını karşılaştırmak için tersimleri açısından farklılık gösterebilecek, ayırt ediciliği yüksek olduğu belirlenmiş $(7,15)$ harflerden " $a, b, d, g, m, r, s$, $\mathrm{u}, \mathrm{v}, \mathrm{y}, \mathrm{z}$ ” harfleri üzerinden karşılaştırmalar yapılmıştır. Örneklerde kullanılan harflerin tersimleri, kaç el hareketi ile yapıldıkları, hangi noktada başlayıp sonlandığı ile ilgili ayrıntılı açıklamalar yapılarak harflerdeki benzerlik ve benzemezlikler saptanmıştır. Görsel inceleme ve karşılaştırmalardan elde edilen verilerin istatistiksel analizleri SPSS 20.0 programı kullanılarak yapılmıştır. Araştırma hipotezlerinin istatistiksel analiz testinde veri tiplerine uygun olarak ki-kare testi kullanılmışıtır. İki sınıflama değişkeni arasında ilişki olup olmadığını test etmek için kullanılan ki-kare testi analizinde değişkenlerin $\mathrm{p}$ değeri hesaplanmıştır. Bu çalışmada 1. tip hata olan $\alpha$ değeri 0.05 olarak kabul edilmiş olup (sosyal alanda yapılan çalışmalarda kabul görmüş bir değerdir), ki-kare testi sonucu çıkan $\mathrm{p}$ değeri ile karşılaştırılarak sonuçlar yorumlanmıştır.

\section{Bulgular}

Tek yumurta ikizlerine yazdırılmış olan büyük ve küçük harf içeren yazı metnindeki harfler şekil özelliklerine göre incelenerek ikizlere ait bulgular tespit edilmiştir. Demografik özellikleri ve anket formuna eklenen bilgiler doğrultusunda elde edilen veriler sinıflandırılarak oranlar ve sayılar hesaplanmıştır.

İkizlerin yaş grupları dağılımı Grafik 1 ve Grafik 2'de sunulmuştur. Çalışmaya katılan gönüllü tek yumurta ikizlerinde minimum yaş 18 maksimum yaş 52 'dir. 50 çift ikizin yaş ortalaması $31(\mathrm{sd}=9.591)$ olarak hesaplanmıştır. İkizlerin eğitim seviyeleri Grafik 3 ve Grafik 4'te sunulmuştur.

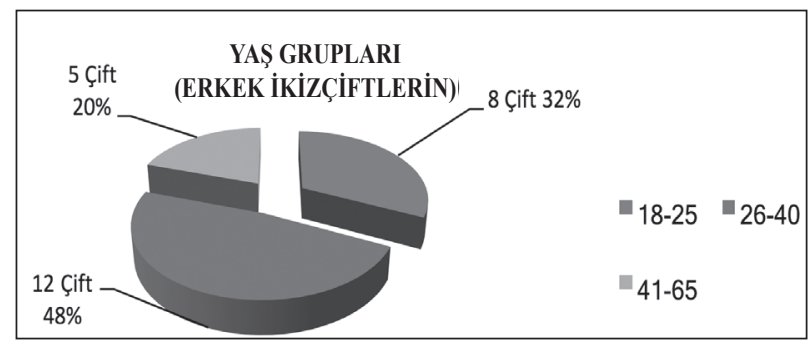

Grafik 1. İkizlerin yaş grup dağılımları (erkek)

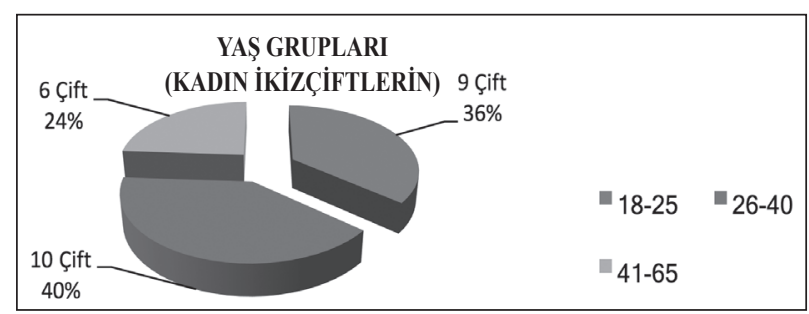

Grafik 2. İkizlerin yaş grup dağılımları (kadın)

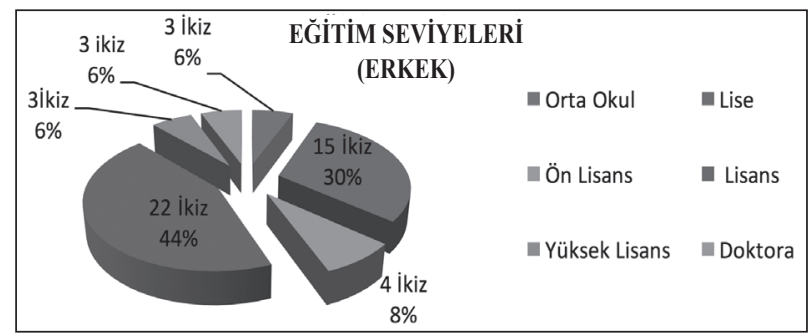

Grafik 3. İkizlerin eğitim seviyeleri (erkek) 


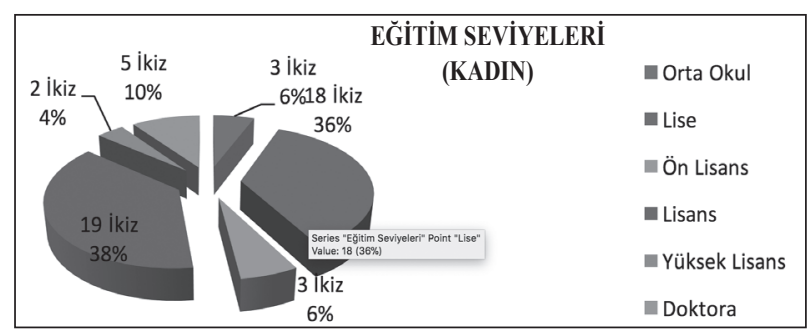

Grafik 4. İkizlerin eğitim seviyeleri (kadın)

El yazısı örnekleri alınan 50 erkek ikizin 45'i (\%90) aktif olarak sağ elini kullanırken 5'i (\%10) sol elini kullanmaktadır. 50 kadın ikizin 48'i (\%96) aktif olarak sağ elini kullanırken 2'si (\%4) sol elini kullanmaktadır. Yazı yazarken ikizi ile aynı eli kullanan 44 (\%88) ikiz, farklı eli kullanan $6(\% 12)$ ikiz olduğu belirlenmiştir. 25 erkek ikiz çiftten 14'ü (\%56) 8-20 yıl, 6'sı (\%24) 21-25 yıl, 5'i (\%20) 26-42 yıl ikizi ile aynı evde yaşadıklarını ifade etmişlerdir. 25 kadın ikizden 13 'ü (\%52) 8-20 yıl, 8'i (\%32) 21-25 yı1, 4'ü (\%16) 26-42 yıl ikizi ile aynı evde yaşadıklarını ifade etmişlerdir. $50 \mathrm{ikiz} \mathrm{çiftin} \mathrm{aynı} \mathrm{evde} \mathrm{birlikte} \mathrm{ya-}$ şama sürelerine bakıldığında minimum 8 yıl, maksimum 42 yıl olup ortalaması $20(\mathrm{sd}=5,919)$ y1l olarak hesaplanmıştır. 25 erkek ikiz çiftten 16's1 (\%64) ilkokulda aynı öğretmenden eğitim aldığını, 9'u (\%36) ise farklı ilkokul öğretmeninden eğitim aldığını belirtmiştir. 25 kadın ikiz çiftten 15 'i (\%60) ilkokulda aynı öğretmenden eğitim aldığını, 10’u (\%40) ise farklı ilkokul öğretmeninden eğitim aldığını belirtmiştir. 50 ikiz çiftten 31'i (\%62) ilkokulda aynı öğretmenden eğitim alırken, 19'unun (\%38) ise fark11 ilkokul öğretmeninden eğitim aldığ 1 saptanmıştır. 50 erkek ikiz çiftin günlük hayatta yazıyı kullanma miktarı 6'sında (\%12) çok sık (30 cümle ve daha fazla), 3'ünde (\%6) oldukça sık (11-30 cümle), 18'inde (\%36) orta s1k (5-10 cümle), 13'ünde (\%26) az (11-30 kelime), 10'unda (\%20) ise çok az (1-10 kelime) şeklinde sınıflandırılmıştır. 50 kadın ikizin günlük hayatta yazıyı kullanma miktarı 10 'unda (\%20) çok sık (30 cümle ve üzeri), 4'ünde (\%8) oldukça sık (11-30 cümle), 28'inde (\%56) orta sik (5-10 cümle), 3'ünde (\%6) az (11-30 kelime), 5'inde (\%10) ise çok az (1-10 kelime) şeklinde sınıflandırılmıştır.

Tek yumurta ikizlerine yazdırılan metin içerisindeki harfler, harflerin yapılış özellikleri, harfin kaç harekette tamamlandığı, kalem kaldırma sayısı, hareket yönü ve başlangıç noktası dikkate alınarak yapılan mikroskobik incelemelere göre 11 harf üzerinden yapılan değerlendirmelerden elde edilen verilerde ortalama benzerlik oranı \%35.63 olup standart sapma 21.71 olarak hesaplanmıştır. El yazılarındaki benzerlik oranlarında en yüksek benzerlik oran $\% 90.90$ iken en düşük benzerlik oran $1 \% 0$ 'dır. 50 çift tek yumurta ikizinin yazmış olduğu el yazılarından seçtiğimiz örnek 2 çift ikizinin el yazılarındaki “ $a, b, d$, g, m, r, ş, u, v, y, z" harflerinin benzerlik sayıları ve oranları, harflerden bazılarının başlangıç ve bitiş noktalarının tersimleri verilen $2 \mathrm{ikiz} \mathrm{çiftine} \mathrm{ait} \mathrm{bulgular} \mathrm{tablo} \mathrm{1.1.,} \mathrm{1,2.}$ 1.3., 2.1., 2.2., 2.3.'te gösterilmiştir.

\section{1. İkiz Çift}

İkizlerin yazmış oldukları metinlerdeki harfler karşılaştırıldığında hiçbir harfte benzerlik gözlemlenmemiş olup, “a, b, d, g, m, r, ş, u, v, y, z" harfler üzerinden hesaplanan benzerlik oranı $\% 0$ olarak tespit edilmiştir (Tablo 1.1.). Çiftlerin kullanmış oldukları bazı harflerin yapılışları Tablo 1.2. ve Tablo 1.3.'te gösterilmiştir.

Tablo 1.1. 1. İkiz çiftin el yazılarındaki “a, b, d, g, m, r, ş, u, v, y, z" harflerinin benzerlik oranları

\begin{tabular}{|c|c|c|c|c|c|c|c|c|c|c|c|c|c|c|}
\hline & & $\mathrm{a}$ & b & d & $\mathrm{g}$ & $\mathrm{m}$ & $\mathrm{r}$ & Ş & $\mathrm{u}$ & $\mathrm{v}$ & $\mathrm{y}$ & $\mathrm{z}$ & \multirow{2}{*}{ TOPLAM } & \multirow{2}{*}{ YÜZDE (\%) } \\
\hline & & \multicolumn{11}{|c|}{ (ikiz çiftlerin sayısı) } & & \\
\hline \multirow{2}{*}{ 1. İKİZ ÇİFT } & $1 \mathrm{~A}$ & \multirow{2}{*}{0} & \multirow{2}{*}{0} & \multirow{2}{*}{0} & \multirow{2}{*}{0} & \multirow{2}{*}{0} & \multirow{2}{*}{0} & \multirow{2}{*}{0} & \multirow{2}{*}{0} & \multirow{2}{*}{0} & \multirow{2}{*}{0} & \multirow{2}{*}{0} & \multirow{2}{*}{0} & \multirow{2}{*}{0} \\
\hline & $1 \mathrm{~B}$ & & & & & & & & & & & & & \\
\hline
\end{tabular}

Tablo 1.2. 1. İkiz çiftin el yazılarındaki "g" harfleri

\begin{tabular}{|l|l|l|}
\hline & \multicolumn{1}{|c|}{ Harfin Yapılış Şekli } \\
\hline İkiz-A & "garfi & $\begin{array}{l}\text { Harf, siyah ok ile belirtilen noktada başlatılarak, "s" şeklinde } \\
\text { devam ettirilmiş olup, tek el hareketi ile yeşil ok ile belirtilen } \\
\text { noktada sonlandırılmıştır. }\end{array}$ \\
\hline İkiz-B & $\begin{array}{l}\text { Harf, siyah ok ile belirtilen noktada başlatılarak, harfin gövdesi } \\
\text { tamamlandiktan sonra tek el hareketi ile harfin kuyruğu yapılarak } \\
\text { yeşil ok ile belirtilen noktada sonlandırılmıştır. }\end{array}$ \\
\hline
\end{tabular}


Tablo 1.3. 1. İkiz çiftin el yazılarındaki "ş" harfleri

\begin{tabular}{|l|l|l|}
\hline & \multicolumn{1}{|c|}{ Harfin Yapılış Şekli } \\
\hline İkiz-A & "ş" Harfi & $\begin{array}{l}\text { Harf, siyah ok ile belirtilen noktada başlatılmış olup, devam } \\
\text { ettirilerek ikinci el hareketi ile harften bağımsız bir bölgede } \\
\text { küçük bir çizgi yapılarak sonlandırılmıştır. }\end{array}$ \\
\hline İkiz-B & $\begin{array}{l}\text { Harf, siyah ok ile belirtilen noktada başlatılarak tek el } \\
\text { hareketi ile devam ettirilerek yeşil ok ile belirtilen noktada } \\
\text { sonlandırılmıştır. }\end{array}$ \\
\hline
\end{tabular}

Tablo 2.1. 2. İkiz çiftin el yazılarındaki “a, b, d, g, m, r, ş, u, v, y, z" harflerinin benzerlik oranları

\begin{tabular}{|c|c|c|c|c|c|c|c|c|c|c|c|c|c|c|}
\hline & & $\mathrm{a}$ & $\mathrm{b}$ & $\mathrm{d}$ & g & $\mathrm{m}$ & $\mathrm{r}$ & ş & $\mathrm{u}$ & $\mathrm{v}$ & $\mathrm{y}$ & $\mathrm{z}$ & \multirow{2}{*}{ TOPLAM } & \multirow{2}{*}{ YÜZDE (\%) } \\
\hline & \multicolumn{11}{|c|}{ (ikiz çiftlerin sayısı) } & & & \\
\hline \multirow{2}{*}{ 2. İKİZ ÇİFT } & $2 \mathrm{~A}$ & \multirow{2}{*}{0} & \multirow{2}{*}{1} & \multirow{2}{*}{1} & \multirow{2}{*}{1} & \multirow{2}{*}{1} & \multirow{2}{*}{1} & \multirow{2}{*}{1} & \multirow{2}{*}{1} & \multirow{2}{*}{1} & \multirow{2}{*}{1} & 1 & \multirow{2}{*}{10} & \multirow{2}{*}{90.90} \\
\hline & $2 \mathrm{~B}$ & & & & & & & & & & & & & \\
\hline
\end{tabular}

\section{2. İkiz Çift}

İkizlerin yazmış oldukları metinlerdeki harfler karşılaştırıldığında “a, b, d, g, m, r, ş, u, v, y, z" harflerinden " b, d, g, m, r, ş, u, v, y, z” harflerinde benzerlikler gözlemlenmiş olup, 11 harf üzerinden hesaplanan benzerlik oranı \%90.90 olarak tespit edilmiştir (Tablo 2.1.). İkiz çiftlerin kullanmış oldukları bazı harflerin yapılışları Tablo 2.2. ve Tablo 2.3.'te gösterilmiştir.

Cinsiyete göre ( $\mathrm{p}=0.119, \mathrm{p}>0.05)$, yaş gruplarına göre $(\mathrm{p}=0.497, \mathrm{p}>0.05)$, meslek gruplarına göre $(\mathrm{p}=0.281$, $p>0.05)$, eğitim seviyesi gruplarına göre $(p=0.940$, $\mathrm{p}>0.05)$, ilkokul öğretmenleri ile $(\mathrm{p}=0.60, \mathrm{p}>0.05)$, aynı evde yaşama süreleri ile ( $\mathrm{p}=0.121, \mathrm{p}>0.05)$, yazıyı kullanma siklıkları ile $(\mathrm{p}=0.640, \mathrm{p}>0.05)$ ve yazı yazarken çiftlerin aynı eli kullanmaları ile $(\mathrm{p}=0.264, \mathrm{p}>0.05)$ el yazılarının benzerlik oranları arasında istatistiksel olarak anlamlı farklılık bulunmamıştır. 25 erkek ikiz çifte tek tek yazdırılan metinde, her bireyin yazısı kendi ikiz çifti ile karşılaştırılmak suretiyle "a, b, d, g, m, r, ş, u, v, y, z" harfleri incelenmiştir. İncelenen bu harflerin yapılış ve boyutları bakımından en fazla benzerlik gösteren harfin "d" harfi olduğu gözlemlenmiş olup, 13 ikiz çift (\%52) bu harfi benzer şekilde kullanmıştır. En az benzerlik gösteren harf ise " $\mathrm{m}$ ve g" harfleri olup, bu harfleri 2 ikiz çiftin (\%8) benzer şekilde kullandığı tespit edilmiştir. 25 kadın ikiz çifte tek tek yazdırılan metinde, her bireyin yazısı kendi ikiz çifti ile karşılaştırılmak suretiyle "a, b, d, g, m, r, ş, u, v, y, z" harfleri incelenmiştir. İncelenen bu harflerin yapılış ve boyutları bakımından en fazla benzerlik gösteren harfin " $r$ " harfi olduğu gözlemlenmiş olup, 17 ikiz çift (\%68) bu harfi benzer şekilde kullanmıştır. En az benzerlik gösteren harf ise " $\mathrm{m}$ " harfi olup, bu harfi 5 ikiz çiftin (\%20) benzer şekilde kullandığı tespit edilmiştir. 25 ikiz çift kadın ve 25 ikiz çift erkekten oluşan toplamda $50 \mathrm{ikiz} \mathrm{çiftin} \mathrm{yazmış} \mathrm{olduğu} \mathrm{metinde,} \mathrm{tersimleri} \mathrm{açısından}$ daha çok farklılık gösterebilir olarak belirlediğimiz "a, b, $\mathrm{d}, \mathrm{g}, \mathrm{m}, \mathrm{r}, \mathrm{s}, \mathrm{u}, \mathrm{v}, \mathrm{y}, \mathrm{z}$ " harfleri çiftlerin yazılarında incelendiğinde harflerin yapılış ve boyutları bakımından en fazla benzerlik gösteren harf "d" harfi olup, 28 çift (\%56) bu harfi benzer şekilde kullanmıştır. En az benzerlik gösteren harf olan "m" harfini ise 7 ikiz çiftin (\%14) benzer şekilde kullandığı tespit edilmiştir.

\section{Tartış̧ma ve Sonuç}

Genetik açıdan birçok benzer özellik gösteren tek yumurta ikizleri adli bilimler açısından ilgi konusu olmuş ve üzerinde oldukça fazla araştırmalar yapılmıştır. El yazıları üzerinde yapılan bazı çalışmalar bulunmakla birlikte geniş çaplı araştırmaların bulunmaması ikizlerin el yazılarının ne derece benzer olduğu, farklı iki kişiye ait el yazısından farklarının olabileceği/olmayacağı ile ilgili olarak merak uyandırmıştır. Bilindiği üzere tek yumurta ikizlerinin genetik özellikleri birbirine benzerdir. Çalışmamızda tek yumurta ikizlerinin benzer genetik kodlara sahip olmalarının el yazılarının benzerliklerinde etkisinin ne derece olduğu, ikiz olmayan iki kardeşten farklı olarak ortak yaşam ve sürelerinin fazla olmasının el yazısının benzer kullanımındaki etkileri gözlenmeye çalışılmıştır. Farklı iki kişiye ait iki el yazısının tamamen aynı olamayacağı bilimsel gerçeğinin ikizlerin el yazıları üzerinde 
Tablo 2. 2. 2. İkiz çiftin el yazılarındaki "z" harfleri

\begin{tabular}{|c|c|c|}
\hline & “z" Harfi & Harfin Yapılış Şekli \\
\hline İkiz-A & & $\begin{array}{l}\text { Harf, siyah ok belirtilen noktada başlatılmış olup, eğimler verilerek } \\
\text { devam ettirilerek, tek el hareketi ile yeşil ok ile belirtilen noktada } \\
\text { sonlandırılmıştır. }\end{array}$ \\
\hline İkiz-B & & $\begin{array}{l}\text { 27.Çift İkiz-B'nin kullanmış olduğu "z" harfi, İkiz-A'nın kullanmış } \\
\text { olduğu "z" harfi ile yapılışları bakımından benzerlik göstermektedir }\end{array}$ \\
\hline
\end{tabular}

Tablo 2.3. 2. İkiz çiftin el yazılarındaki " $\mathrm{g}$ " harfleri

\begin{tabular}{|l|l|l|}
\hline \multicolumn{1}{|c|}{ "g" Harfi } & \multicolumn{1}{c|}{ Harfin Yapılış Şekli } \\
\hline İkiz-A & $\begin{array}{l}\text { Harf, siyah ok ile belirtilen noktada başlatılarak, harfin gövdesi } \\
\text { tamamlandıktan sonra tek el hareketi ile harfin kuyruğu } \\
\text { yapılarak yeşil ok ile belirtilen noktada sonlandırılmıştır. }\end{array}$ \\
\hline İkiz-B & $\begin{array}{l}\text { 27.Çift İkiz-B'nin kullanmış olduğu "g" harfi, İkiz-A'nın } \\
\text { kullanmış olduğu "g" harfi ile yapılişları bakımından benzerlik } \\
\text { göstermektedir }\end{array}$ \\
\hline
\end{tabular}

de etkisinin miktarının belirlenmesi, yazı ile ilişkili kriminal bir olayda şüpheli kişilerin tek yumurta ikizi varsa adaletin doğru tecelli etmesi açısından, elde ettiğimiz verilerin incelemeye dahil edilip edilemeyeceği ile ilgili bir fikir oluşturması hedeflenmiştir.

El yazıların incelediğimiz 50 ikiz çiftten hiçbir çiftin el yazısında $\% 100$ benzerlikler gözlenmemiş olup, $5 \mathrm{ikiz}$ çiftin $(\% 10)$ el yazılarındaki benzerlik oranı $\% 0$ olarak tespit edilmiştir. SPSS 20.0 programı kullanılarak yapılan hesaplamalarda el yazılarının benzerlik ortalaması \%35.63 olup, standart sapması 21.71 olarak hesaplanmıştır. Bu nedenle ikizlerin el yazılarında yüksek oranda benzerlikler saptansa da tamamıla benzediği söylenemez.

Adli belge inceleme, el yazısı ile ilgili temel bilimsel gerçekler üzerine kurulmuştur. İlk ve en temel bilimsel gerçek, iki bireyin el yazısının birbiriyle tamamen aynı olamayacağı, ikinci önemli gerçek ise el yazısında kullanılan bazı harflerin diğerlerine kıyasla daha fazla değişken karakteristik özelliğe sahip olmaları ve bu bağlamda diğer harflere göre daha fazla benzemezlik içermeleridir (16). İkizler üzerinde yapılan çalışmamızda, diğer harf- lere göre benzemezlik özelliği daha fazla olan 11 harf üzerinden bir karşılaştırma yapılmış olup, ilk ve en temel bilimsel gerçek olarak bahsedilen "iki bireyin el yazısının tamamen aynı olamayacağı" görüşü ile uyumlu sonuçlara ulaşılmıştır. Bu durumda ikizlerin benzer genetik kodlara sahip olmalarının, el yazısının benzerlik göstermesi üzerinde tek başına etkisinin olmadığı tespit edilerek, harflerin benzemezlik özelliğinin ikiz olan bireylerin el yazıları için de geçerli olduğu sonucuna ulaşılmıştır.

Cinsiyetin el yazılarının benzerlik oranları üzerindeki etkisi incelendiğinde; 25 çift kadın ve 25 çift erkek ikizin ortalama el yazı benzerlik oranları kadın çiftlerde $\% 44.36$, erkek çiftlerde ise $\% 26.18$ olarak hesaplanmıştır. Erkek ikiz çiftlerin el yazılarındaki en yüksek benzerlik oranı \%54.54 iken, 4 (\%16) erkek çiftin el yazılarının benzerlik oranı $\% 0$ olarak tespit edilmiştir. Yapılan analiz sonucunda cinsiyetin el yazılarının benzerlik oranları üzerinde istatistiksel açıdan anlamlı farklılık bulunmamıştır ( $p=0.119, p>0.05$ ). Ancak kadın çiftlerde en yüksek benzerlik oranının \%90.90 olması ve sadece $1(\% 4)$ kadın çiftin el yazılarının benzerlik oranının $\% 0$ olarak 
hesaplanması, cinsiyetin el yazıları üzerinde etkili olabileceğini ve kadın çiftlerin el yazılarının erkek çiftlerin el yazılarına oranla daha fazla benzerlik gösterdiği yönünde değerlendirilmiştir.

Fourier yönteminin geçerliliğini inceleyen bir çalışmada a, d, o ve q harflerinin benzerliği tespit etme bakımından önem derecesi incelenmiştir. İlk aşamada bu karakterlerin ayırt edici gücü tespit edilmiş ve d harfi en güçlü ayırt edici parametre olarak yüzde 82.4 oranıyla teyit edilmiştir (17). Çalışmamızda ikizlerin en çok benzer olarak kullandığı harfler sırası ile "d, b, v, y-z, u, a, ş, g, m" şeklinde tespit edilmiş olup, ikiz çiftlerin kullanmış oldukları harflerden; harflerin yapılış ve boyutları bakımindan en fazla benzerlik gösteren harfin "d" harfi olduğu saptanmış ve 28 ikiz çiftin (\%56) bu harfi benzer şekilde kullandığı saptanmıştır. İncelememizde "d" harfinin ayırt edici gücü en düşük harf olarak tespit edilmesi ile literatürden farklı bir sonuç elde edilmiştir. En az benzerlik gösteren harf ise " $m$ " harfi olup, 7 çiftin (\%14) bu harfi benzer şekilde kullandığı tespit edilmiştir.

Srihari ve ark. (2008) tarafindan yapılan benzer bir çalışmada incelenen 206 ikiz çiftinin el yazısının ayırt edilmesi amaçlanmış, elde edilen sonuçlar ikiz olmayan bireylerin el yazısıyla karşılaştırılmıştır. Araştırmanın sonucunda, ikiz çiftlerin el yazısı birbirinden ayırt edilebilmiş ancak oransal başarı düzeyi ikiz olmayanların el yazısına kıyasla daha düşük seviyede olduğu bildirilmiştir

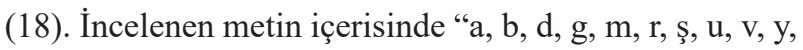
z" harflerinin çiftler içinde kullanımındaki benzerlikler; erkek ikiz çiftlerde, kadın ikiz çiftlere oranla daha az görülmüş olup, ikiz erkek çiftlerin en çok benzer kullandıkları harfler sırası ile "d, v-z, y-r-b, v, a, ş, g-m" iken, ikiz kadın çiftlerde bu sıra şu şekildedir; "r, b-d, v, y, z-u, a, ş, g, m'. Her iki karşılaştırmada da en az benzer olarak "m" harfi kullanılmış olup, "m" harfi ikizlerin kullandığı harflerden benzemezlik özelliği en yüksek olan harf olarak tespit edilmiştir. Çalışmamızda elde ettiğimiz veriler, Shari ve ark.nın çalışması ile uyumlu bulunmuştur.

İkizlerin yaş gruplarının el yazılarının benzerlik oranları ile yapılan karşılaştırmalarımızda her aralıkta değişken sonuçlar gözlemlenmiş olup analiz sonucunda istatistiksel açıdan anlamlı bir farklılık gözlenmemiştir $(\mathrm{p}=0.497, \mathrm{p}>0.05)$.

İkizlerin aynı mesleği yapıyor olması ile el yazılarının benzerlik oranları arasındaki ilişki incelendiğinde, farklı meslekte olan $5(\% 10)$ ikiz çiftin el yazılarındaki en düşük benzerlik oran $1 \% 0$ olarak hesaplanmış ve farklı meslekte olan ikizlerin el yazılarının benzerlik oranlarının en yüksek \%81.81 olduğu gözlenmiştir. Aynı mesleği yapan ikizlerin el yazılarındaki benzerlik oranları incelendiğinde en düşük benzerliğin \%18.18 en yüksek benzerliğin ise $\% 90.90$ olduğu tespit edilmiştir. İstatistiksel açıdan anlamlı farklılıklar bulunmamıştır ( $\mathrm{p}=0.281, \mathrm{p}>0.05)$.

İkizlerin eğitim seviyelerinin aynı düzeyde olması ile el yazılarının benzerlik oranları arasındaki ilişkiyi incelediğimizde eğitim seviyeleri farklı olan ikizlerin, el yazılarındaki en yüksek benzerlik oranı \%63.63'tür. Bu oran eğitim seviyeleri aynı olan ikizlerde \%90.90'a kadar çıkmaktadır. Yapılan analizlerde istatistiksel açıdan anlamlı farklılık bulunmamıştır ( $\mathrm{p}=0.940, \mathrm{p}>0.05$ ).

Çalışmamızda bir başka incelenen değişken verimiz ise çiftlerin aynı ilkokul öğretmeninden eğitim almış olmalarıdır. Kişide yazı karakterleri öğrencinin ilkokul öğretmeninin kullandığı harfleri şekil olarak taklit etmesiyle başlar. Bu sebeple aynı öğretmenden eğitim alan öğrencilerin el yazılarında benzer karakterlerin olma ihtimali daha yüksek olduğu düşünülebilir. 50 ikiz çiftin verilerine bakıldığında 31 (\%62) ikiz çiftin aynı ilkokul öğretmeninden eğitim aldıkları, 19 (\%38) ikiz çiftin ise farklı ilkokul öğretmenlerinden eğitim aldıkları tespit edilmiştir. Elde edilen verileri incelediğimizde el yazıları benzerlik oranları \%54.54 ile \%90.90 arasında olan ikiz çiftlerin hepsinin ilkokul öğretmenlerinin aynı olduğu, el yazı benzerlik oranları \%54.54'ün altında olan çiftlerin ise ilkokul öğretmenlerinin aynı ve farklı olarak değişkenlik gösterdiği görülmüştür. Farklı ilkokul öğretmenine meylin azalmasıyla el yazılarının benzerlik oranlarının artışının olması ve p değerinin 0.60 tespit edilmesiyle analizin anlamlıya yakın olduğu görülmüşse de bu karşılaştırmada istatistiksel açıdan anlamlı farklılık bulunmamıştır $(\mathrm{p}=0.60, \mathrm{p}>0.05)$.

İkizlerin el yazılarının benzerlik oranları ile ikizlerin aynı evde yaşama sürelerini incelediğimizde ikizlerin birlikte yaşama süreleri 8-20 y1l, 21-25 y1l, 26-42 yıl şeklinde üç sınıfa ayrılmıştır. 8-20 yıl aralığında aynı evde yaşamış olan ikizlerin el yazılarının benzerlik oranlarına bakıldığında en yüksek oran \%54.54, 21-25 y1l aralığında aynı evde yaşamış ikizlerin el yazılarının benzerlik oranlarına bakıldığında en yüksek oran $\% 81.81$ ve $26-42$ yıl aralığında aynı evde yaşamış olan ikizlerin el yazılarının benzerlik oranları ise en yüksek \%90.90 olarak tespit edilmiştir. Bu durumda ikizlerin aynı evde yaşama süreleri arttıkça el yazılarının benzerlik oranlarında da sıralı bir artışın olduğu gözlenmiştir. Ancak yapılan analiz sonucunda istatistiksel açıdan anlamlı farklılık saptanmamıştır $(\mathrm{p}=0.121, \mathrm{p}>0.05)$.

Yazma eylemi küçük yaşlardan itibaren başlayan öğrenme ve uygulama safhasının yıllar içerisinde birçok aşamayı geçerek tamamladığı bir süreçtir. Ancak artık mükemmele ulaştı denildiğinde bile sürekli küçük değişimlere açıktır. Bu nedenle iyi bir adli belge inceleme uzmanının el yazısının şekillenmesinde etkili olan etken ve 
süreçlerden olabildiğince haberdar olması gereklidir (19). Kişiye özgü olan tersim tarzı, taklit edilmesi en zor parametrelerdendir. Beyindeki yazı merkezlerini etkileyen olağandışı bir durum söz konusu olmadıkça tersim tarzı değişikliğe uğramaz. İstemli olarak değiştirilmeye çal1şılsa da devamlı olması mümkün değildir. Düşüncelerin bir bakıma resmedilişi olan bu unsur adli belge incelemelerinde en önemli kriterlerin başında gelmektedir (6). El yazılarının benzerlik oranlarında, ikizlerin yazıyı aynı sıklıkta kullanmaları ve aynı eli kullanmaları arasındaki ilişki incelendiğinde herhangi bir ayırıcı unsur gözlenmemiştir. Bu durumda yazının kullanılma sıklığında standart bir değişimin olmamasının, kişide yazı karakterlerinin oturmasından kaynaklanmaktadır. Dominant olarak kullanılan elin el yazılarının benzerlik oranları üzerinde bir etkisinin tespit edilememesinde küçük yaşlardan itibaren dominant olarak kullanılan elin değişmemesi ve yazı karakterinin bu elde oturmasıyla ilişkilidir. Yapılan analizlerde ikizlerin el yazılarının benzerlik oranları üzerinde, ikizlerin yazıyı aynı sıklıkta kullanmalarının ve ikizlerin yazı yazarken aynı eli kullanmalarının istatistiksel açıdan anlamlı farklılıkları bulunmamıştır $(\mathrm{p}=0.640, \mathrm{p}<0.05)$, $(\mathrm{p}=0.264, \mathrm{p}>0.05)$.

Yazının öğrenilmesi iradeli kazanım usulüyle gerçekleşmektedir. Bunun en yalın şekli algılanan örneğin taklit edilmesidir. Kişiler harf konstrüksiyon tekniğini ne şekilde öğrenmişlerse hayatları boyunca genellikle aynı şekilde uygularlar. Öğrenme tekniği kişilerin el yazllarının özelliklerini belirleyen önemli bir unsur ise de kişiler kendi yazılarını geliştirirler. Yazıları her özelliği ile aynı olan iki farklı kişinin bulunması imkânsızdır (20). Genel şekil yönünden incelenen tüm parametreler göz önüne alındığında, ikiz olmayan bireylerin el yazıları arasında yapılan karşılaştırmalarda elde edilen sonuç iki el yazısının tamamen aynı olamayacağı ve harflerin benzemezlik özelliğinin ikiz olan bireylerin el yazıları içinde geçerli olduğudur. Tıpkı tek yumurta ikizlerinin tamamen benzer oldukları kanısının yanlışlığ 1 ispat edildiği ve parmak izlerinin birbirinden farklı olduğu bilimsel gerçeği gibi, el yazılarında da bu yönde bir özellik göstererek, kısmi ya da azımsanmayacak benzerlikler saptansa da yazıların birbirinden farklı olduğu sonucuna ulaşılmıştır.

El yazısı incelemeleri adli bilimler açısından iki kişinin el yazısının birbirinden ayırt edilebilmesi açısından büyük önem taşımaktadır. Birbirine çok benzediği düşünülen iki farklı el yazısının bile bir el yazısı inceleme uzmanı tarafından incelendiğinde farklılıklar içerdiği görülür. Adli boyutuyla incelenen bu yazıların, adli mercilere intikal ettiği durumlarda suçlunun tespiti açısından önem arz eder. İncelenecek yazılarda titiz ve bilinçli bir çalışma yürütülür. Bu durumdaki ilk aşama incelenecek belgelerin korunmasından başlamaktadır. Çalışmamızda tek yumurta ikizlerine ait elde edilen bu bulgularda olası adli bir vakada incelemeciye yardımcı nitelik taşıması açısından değer katmaktadır.

Adli kimliklendirmelerde şekil özelliklerine göre değerlendirilen harflerin başlangıç ve bitiş noktaları tespit edilmesi, tespit edilen bu noktaların hareket yönü, başlangıç ve bitiş özellikleri, kalem kaldırma sayıları, harfin kaç harekette tamamlandığı gibi karşılaştırmalara göre değerlendirmeler yapılmaktadır. Adaletin tecelli etmesi muhtemel bir vakada da yapılan bu değerlendirmeler uzman kişinin taklit ya da bilinçli değiştirme ile yazılan yazıları incelemesiyle sonuca ulaşır. Herhangi iki yazı karşılaştırılırken ne derece benzerliklerin olduğu tespit edilir. Çalışmamızda el yazı örneklerini aldığımız 50 çift tek yumurta ikizinin kendi çiftinin el yazısıyla ne derece benzerlikler gösterdiği ve benzerlik/benzemezliklere hangi faktörlerin etkisi olabileceği üzerinde incelemeler yapılmıştır. İkizlerin cinsiyetlerinin, yaşlarının, aynı meslekte bulunmalarının, eğitim seviyelerinin aynı olmasının, aynı evde yaşama sürelerinin, yazıyı kullanma sıklıklarının, yazı yazarken çifti ile aynı eli kullanmış olmalarının ikizlerin el yazılarının benzerlik oranlarına etkileri üzerinde çalışılmıştır. İkizlerin çifti ile yapılan bu karşılaştırmalarda istatistiksel açıdan anlamlı farklılıkların bulunmadığı tespit edilmiştir. Ancak ikizlerin yazılarının birebir aynı olmadığı bilimsel gerçeğine ulaşılmış olması ve yazılardan kimliklendirme çalışmasında tanı koydurucu özellikler de olması adli bilimler alanında çok önemli bir yere işaret etmektedir. El yazısı karşılaştırmalarında, daha fazla benzemezlik özelliği gösteren harflerin incelenmesinin yanı sıra sonucu desteklemek adına kalan harflerde incelenerek, yazı bir bütün olarak değerlendirilmelidir.

İkizlerin el yazılarında kullanılan harf karakterlerinin, kelime ilişkilerinin, yazı şekillerinin ve stillerinin birbirine benzer nitelikte olduğu görülmüştür. Elde edilen verilerde ortalama benzerlik oran $\% 35.63$ olup standart sapma 21.71 olarak hesaplanmıştır. Değerlendirilen harfler üzerinden tespit edilen en yüksek benzerlik oranı $\% 90.90$ iken en düşük benzerlik oranı ise \%0'dır. İkizlerinin el yazılarında yüksek oranda benzerlikler tespit edilmiş olsa da ayırt edici özelliklerin olduğu saptanmıştır. El yazılarında \%100 benzerliklerin bulunmadı $\breve{g}_{1}$ tespit edilmiş olup, iki bireyin el yazılarının tamamen aynı olamayaca$\breve{g} 1$ ilkesinin ikizlerin el yazıları içinde geçerli olduğu sonucuna ulaşılmıştır. Bu tür ayırt edici özelliklerin kişisel el yazısını belirleyen temel unsurlar olduğu, her bireyin kullandığı kendine özgü bir yazı karakterinin olmasından kaynaklandığı bilinmektedir. 


\section{Teşekkür}

Makaleye sağladığı yardım ve destek için Sayın Doç. Dr. Nergis Cantürk'e ve Sayın Ebru Korkem Özcan ile bu çalışmanın temelini oluşturan, zaman ayırarak el yazılarını kaleme alan bütün tek yumurta ikizlerine içten teşekkürlerimi sunarım.

\section{Kaynaklar}

1. Birincioğlu İ. Örneklerle El Yazısı İnceleme Teknikleri ve Prensipleri. Așıcıoğlu F, editör. Adli Bilimlerde El Yazısı ve İmza İncelemeleri. İstanbul: Öner Matbaacılık; 2007. s. 127.

2. Sala S. Yazı ve İmza Nedir? Çağdaş Anlamda El Yazısında Kullanılan Enstrümanlar Nelerdir? Aşıŏlu F, editör. Adli Belge İncelemesi. İstanbul: Beta Basım; 2005. s. 30.

3. Bafra J. El Yazısı İncelemelerinde "Kișisel Yazı Unsurlarının İsteyerek Değiştirilmesi” Problemi ve Kimlik Belirlenmesi (Doktora Tezi). İstanbul: İstanbul Üniversitesi, Adli Tıp Enstitüsü; 1995.

4. Bird C, Found B, Rogers D. Forensic document examiners' skill in distinguishing between natural and disguised handwriting behaviors. Journal of Forensic Sciences 2010;55(5):1291-5. DOI: 10.1111/j.15564029.2010.01456.x

5. Found B, Ganas J. The management of domain irrelevant context in formation in forensic handwriting examination case work. Scienceand Justice 2013;53:154-8. DOI: 10.1016/j.scijus.2012.10.004

6. Özcan E. Latin Harflerini Kullanan Bireylerin Ana Dil, Yabancı Dil ve Hiç Bilmedikleri Bir Dildeki El Yazı Örneklerinin Adli Belge İnceleme Yönünden Değerlendirilmesi (Master Tezi). Tez Danışmanı: Cantürk N. Ankara: Ankara Üniversitesi, Adli Bilimler Enstitüsü; 2016.

7. Birincioğlu İ, Özkara E. Adli Belge İncelemelerinde Bilinmeyenler, Örneklerle Yazı ve İmza Analizi ile Islak İmza Kavram1. TBB Dergisi 2010;87:403-3.

8. Güneş F. Okumada Küçük Harflerin Büyük Gücü. Ad1yaman Üniversitesi Sosyal Bilimler Enstitüsü Dergisi 2012;5(10):93-08.

9. Çınar T. El Yazısı ve İmza İncelemeleri. Aşıcıŏglu F editör. Adli Belge İncelemesi. İstanbul: Beta Basım; 2005. s.70.
10. Tıraş B. (İnternet). Tek Yumurta İkizleri. (Erişim Tarihi: 24 Ocak 2016) Erişim: http://jinekoloji.com/tek-yumurta-ikizleri.

11. Machin G. Non-identical monozygotic twins, intermediate twin types, zygosity testing, and the non-random nature of monozygotic twinning: A review. American Journal of Medical Genetics 2009;151C:110-7. DOI: 10.1002/ ajmg.c.30212

12. Ketelaar ME, Hofstrab RMW, Hayden MR. What monozygotic twins discordant for phenotype illustrate about mechanismsin fluencing geneticforms of neurodegeneration. Clinical Genetics 2012;81:325-33. DOI: 10.1111/j.13990004.2011.01795.x

13. Bayan OM, Shamsuddin SM. Feature discretization for individuality representation in twins handwritten identification. Journal of Computer Science 2011;7:1080-7. DOI : 10.3844/jcssp.2011.1080.1087

14. Mohammed BO, Shamsuddin SM. Improvement in twins hand writing identification with in variants discretization. EURASIP Journal on Advances in Signal Processing 2012;48:1-12. DOI: 10.1186/1687-6180-2012-48

15. Zhang B, Srihari SN, Lee S. Individuality of Handwritten Characters. 7th International Conference on Document Analysis and Recognition, Edinburgh, Scotland, 2003; 1-5. DOI: 10.1109/ICDAR.2003.1227824

16. Koppenhaver KM. Forensic Document Examination: Principles and Practice. New: Humana Press Inc., 2007: p.91. DOI: 10.1007/978-1-59745-301-1

17. Marquis R, Taroni F, Bozza F, Schmittbuh M. Quantitative characterization of morphological poly morphism of handwritten characters loops. Forensic Science International 2006;164:211-20. DOI: 10.1016/j.forsciint.2006.02.008

18. Srihari S, Huang C, Srinivasan H. On the discriminability of the handwriting of twins. Journal of Forensic Sciences 2008;53(2):430-46. DOI: 10.1111/j.15564029.2008.00682.x

19. Aşıcıoğlu F. Yazı ve İmzada Değişen Koşul ve Etmenlere Bağlı Farklılıklar. Aşıcıoğlu F editör. Adli Bilimlerde El Yazısı ve İmza İncelemeleri. İstanbul: Öner Matbaacıllk; 2007. s.91.

20. Kurtaş Ö. El Yazısında Temel Tanımlar ve Kurallar (El Yazısı Tanı Unsurları). Aşıcıoğlu F editör. Adli Bilimlerde El Yazısı İncelemeleri. İstanbul: Öner Matbaacılık; 2007. s.33. 